\title{
ISOLASI DAN KARAKTERISASI RHIZOBAKTERI YANG BERPOTENSI SEBAGAI AGEN PEMACU PERTUMBUHAN TANAMAN
}

\section{ISOLATION AND CHARACTERIZATION OF RHIZOBACTERIAL POTENTIAL AS PLANT GROWTH PROMOTING AGENTS}

\author{
Eko Hary Pudjiwati ${ }^{1)}$, Siti Zahara ${ }^{2)}$, Dewi Sartika ${ }^{3)}$ \\ 1,2,3) Jurusan Agroteknologi, Fakultas Pertanian, Universitas Borneo Tarakan \\ Jalan Amal Lama Nomor 1, Tarakan \\ Email: ${ }^{1}$ inok3959@gmail.com
}

\begin{abstract}
ABSTRAK
Penelitian bertujuan untuk mendapatkan isolat rizobakteri yang memiliki aktifitas melarutkan fosfat, memproduksi enzim protease, dan memiliki aktifitas anti-fungal terhadap cendawan fitopatogen Fusarium oxysporum secara in vitro. Isolasi rizobakteri dilakukan di Laboratorium Perlindungan Tanaman Fakultas Pertanian Universitas Borneo Tarakan dari sampel tanah yang diambil dari daerah di sekitar Kota Tarakan, Kalimantan Utara dengan media Nutrient Agar (NA). Isolat bakteri yang diperoleh diuji keamanannya sebagai agens hayati dengan cara menumbuhkan benih timun yang telah direndam dalam suspensi bakteri. Bakteri yang aman (tidak berpotensi sebagai fitopatogen) kemudian dikarakterisasi fenotipnya dan sifat fisiologisnya. Sifat fisiologis yang diamati adalah kemampuan dalam menghasilkan enzim protease (pada media Skim Milk Agar, Merck, Germany) dan kemampuannya dalam melarutkan fosfat (pada media Pikovskaya Agar, HiMedia, India). Selanjutnya juga diuji kemampuannya dalam menghambat pertumbuhan $F$. oxysporum secara in vitro. Hasil penelitian meunjukkan bahwa diperoleh 35 isolat rhizobakteri yang non patogenik, 23 isolat rhizobakteri yang memiliki aktivitas proteolitik, 2 isolat rhizobakteri yang mampu melarutkan Fosfat dan tidak ada isolat rhizobakteri yang memiliki kemampuan antifungal.
\end{abstract}

\section{Kata Kunci : Isolat; Rhizobakteri; Agen; Pemacu Pertumbuhan Tanaman;} Karakterisasi

\begin{abstract}
The aim of this study was to obtain rizobacterial isolates that have phosphatedissolving activity, produce protease enzymes, and have anti-fungal activity against Fusarium oxysporum fungus in vitro. Rhizobacterial isolation was carried out at the Laboratory of Plant Protection Laboratory of the University of Borneo Tarakan from soil samples taken from the area around the City of Tarakan, North Kalimantan with Nutrient Agar (NA) media. Bacterial isolates obtained were tested for safety as biological agents by growing cucumber seeds that have been immersed in bacterial suspensions. Bacteria that are safe (no potential as phytopathogens) are then characterized by their phenotype and physiological properties. The physiological properties observed were the ability to produce protease enzymes (on Skim Milk Agar, Merck, Germany) and their ability to dissolve phosphate (on Pikovskaya Agar media, HiMedia, India). Furthermore, it was also tested for its ability to inhibit the growth of $F$. oxysporum in vitro. The results showed that there were 35 nonpathogenic rhizobacterial isolates, 23 rhizobacterial isolates which had proteolytic
\end{abstract}


activity, 2 rhizobacterial isolates that were able to dissolve Phosphate and there were no rhizobacterial isolates that had antifungal ability.

\section{Keywords: Isolate; Rhizobacterial; Characterization \\ Agents; Plant Growth Promoting;}

\section{PENDAHULUAN}

Kebutuhan manusia tidak terlepas dari kebutuhan pangan, maka pangan menjadi suatu kebutuhan yang penting. Saat ini kebutuhan pangan paling banyak dipenuhi dari tanaman, baik dari bagian daun, biji, maupun umbi. Pertumbuhan tanaman dipengaruhi oleh banyak faktor, baik faktor internal maupun eksternal. Selanjutnya pertumbuhan tanaman juga dipengaruhi oleh munculnya organisme penganggu tanaman (OPT) baik dari golongan hama maupun patogen tanaman. Salah satu patogen yang umum ditemui di Indonesia dan daerah tropis lainnya adalah cendawan fitopatogen Fusarium oxysporum (Ploetz, 2006). Cendawan ini dilaporkan menginfeksi berbagai jenis tanaman penting seperti cabai, pisang, bawang, sawit, dan lada (Nurulhuda et al. 2009). Infeksi F. oxysporum dapat mengakibatkan kehilangan hasil yang cukup tinggi (sampai dengan 70\%). Beberapa peneliti melaporkan infeksi $F$. oxysporum yang bersinergi dengan patogen lain seperti nematoda Meloidogyne sp., dan Radopholus similis dapat mengakibatkan gagal panen pada berbagai komoditas pertanian (Meena et al., 2015; Meena et al., 2016).

Berbagai penelitian telah dilakukan untuk mengatasi masalah ini, namun penyakit layu Fusarium pada berbagai komoditas pertanian masih menjadi masalah yang sepenuhnya belum teratasi. Salah satu solusi yang efektif dan ramah lingkungan untuk mengendalikan cendawan ini adalah aplikasi agen hayati. Penggunaan agen hayati dari kelompok rizobakteri untuk menekan infeksi $F$. oxysporum telah beberapa kali dilaporkan
(Lecomte et al., 2016; Paramanandham et al., 2017). Sifat agen hayati yang semispesifik lokasi menyebabkan beberapa agen hayati yang telah dilaporkan tidak dapat digunakan pada lokasi lain. Selanjutnya agen hayati dari kelompok rizobakteri juga diketahui mampu mengendalikan nematoda yang bersinergi dengan $F$. oxysporum seperti $M$. incognita, Radopholus similis, dan Pratylenchus brachyurus pada skala laboratorium, rumah kaca, dan lapangan (Castillo et al., 2017; Xiang et al., 2017).

Rizobakteri diketahui memiliki banyak mekanisme yang bermanfaat untuk pertumbuhan tanaman. Sebagai agens pelindung tanaman rizobakteri mampu memproduksi bahan campuran antimikroba, siderofor, enzim lisis, dan menginduksi tanaman agar lebih resisten terhadap infeksi patogen (Liu et al., 2017). Sebagai Plant Growth Promoter rizobakteri mampu memproduksi hormon-hormon pertumbuhan yang dibutuhkan oleh tanaman, menambat nitrogen $(\mathrm{N})$, melarutkan fosfor $(P)$, dan menginduksi ketahanan tanaman terhadap cekaman lingkungan (salinitas tinggi, $\mathrm{pH}$ rendah, dan keterbatasan unsur hara). Mekanisme rizobakteri dalam menginduksi ketahanan adalah dengan mengkolonisasi jaringan tanaman sehingga tanaman terstimulasi memproduksi senyawa metabolit yang berperan untuk ketahanan tanaman (Breedt et al., 2017; Furlan et al., 2017; Rubin et al., 2017).

Gupta et al., (2015) melaporkan aplikasi rizobakteri pelarut fosfat di tanah masam efektif melarutkan $\mathrm{Ca}_{3}\left(\mathrm{PO}_{4}\right)_{2}$, $\mathrm{AlPO}_{4}$, dan $\mathrm{FePO}_{4}$ sehingga tersedia bagi tanaman. Rizobakteri dari kelompok 
Acetobacter diazotrophicus juga dilaporkan mampu memproduksi indole-3-acetic acid yang memiliki peran penting dalam pertumbuhan tanaman di tanah masam. Bakteri probiotik Bacillus pantothenticus galur P4 (MTCC 4695) dan Pseudomonas pieketti galur Psd6 (MTCC 4715) yang dilaporkan oleh Thakuria et al., (2004) mampu meningkatkan hasil panen padi di tanah masam sampai dengan 76,9\%. Peningkatan hasil tersebut dipengaruhi oleh kemampuan rizobakteri dalam menghasilkan IAA sampai dengan 21,6 $\mu \mathrm{g} / \mathrm{mL}$ dan aktifitas nitrogenase isolat bakteri tersebut.

Penelitian ini bertujuan untuk mendapatkan isolat rizobakteri yang memiliki aktifitas melarutkan fosfat, memproduksi enzim protease, dan memiliki aktifitas anti-fungal terhadap cendawan fitopatogen Fusarium oxysporum secara in vitro.

\section{METODE PENELITIAN}

Penelitian dilaksanakan pada bulan September sampai dengan bulan November 2017 di Laboratorium Perlindungan Tanaman, Fakultas Pertanian, Universitas Borneo Tarakan.

Rizobakteri diisolasi dari tanah di Kota Tarakan, Kalimantan Utara. Sebanyak $10 \mathrm{~g}$ sampel tanah dicampur dengan $100 \mathrm{ml}$ akuades steril dan dikocok hingga homogen. Selanjutnya suspensi tersebut diencerkan menggunakan pengenceran berseri sampai pengenceran 10-4. Sebanyak $100 \mu \mathrm{ll}$ suspensi hasil pengenceran kemudian diratakan pada cawan petri berisi media Nutrient Agar (NA) $20 \%$ menggunakan microbiology glass bead lalu diinkubasi selama 48 jam. Isolasi bakteri dilakukan dengan dua ulangan (duplo) (Penrose dan Glick, 2003). Rizobakteri yang memiliki karakter fenotip yang berbeda diambil menggunakan disposable oose dan ditumbuhkan pada cawan petri berisi media NA $100 \%$.

\section{Uji Patogenesitas}

Isolat bakteri ditumbuhkan pada media Nutrient Broth (NB) selama 48 jam. Selanjutnya benih mentimun varietas Mercy direndam dalam suspensi tersebut selama 24 jam. Benih yang telah direndam selanjutnya ditumbuhkan pada cawan petri dengan alas kertas saring steril. Benih timun dipelihara selama 2 minggu dan disiram menggunakan akuades steril. Pengamatan dilakukan terhadap munculnya gejala pada bibit timun yang diuji. Isolat bakteri yang menimbulkan gejala keriting, layu, rebah, busuk, hawar, nekrosis, klorisis, dan menyebabkan terhambatnya perkecambahan benih mentimun tidak digunakan pada pengujian selanjutnya (Pradana, 2016).

\section{Karakterisasi Fenotip Koloni Bakteri}

Pengamatan fenotip koloni rizobakteri diamati berdasarkan bentuk koloni, ukuran, tekstur, warna, dan elevasi (Bochner, 2008), pada lup inokulasi (Buck, 1982).

\section{Uji Kemampuan Bakteri Endofit dalam Menghambat Pertumbuhan Fusarium oxysporum (In Vitro).}

Isolat $F$. oxysporum berasal dari koleksi Laboratorium Nematologi Tumbuhan, Departemen Proteksi Tanaman, Institut Pertanian Bogor. F. oxysporum ditumbuhkan bersamaan dengan bakteri endofit pada medium potato dextrose agar (PDA) (Himedia, India). Bakteri endofit ditumbuhkan pada bagian tengah cawan petri, kemudian F. oxysporum ditumbuhkan pada $1 / 4$ bagian dari cawan petri. Uji ini diulang 2 kali. Pertumbuhan $F$. oxysporum yang mengarah ke arah bakteri dan berlawanan arah dengan bakteri diukur pada hari ke-5 dengan menggunakan rumus:

$$
\mathrm{P}=\frac{\mathrm{R} 1-\mathrm{R} 2}{\mathrm{R} 1} \times 100 \%
$$


JURNAL BORNEO SAINTEK

Volume 2, Nomor 2, Oktober 2019

e-ISSN 2599-3313

p-ISSN 2615-434X

Dimana:

$\mathrm{P}=$ persentase penghambatan pertumbuhan (\%);

R1 = jarak jari-jari miselium hingga tepi cawan petri $(\mathrm{cm})$;

R2= jarak jari-jari miselium hingga tepi zona hambat (cm) (Karim et al., 2015).

\section{Uji Aktivitas Proteolitik}

Aktivitas proteolitik diuji menggunakan media susu skim agar pada $\mathrm{pH}$ 6.5. Komposisi media terdiri atas $10 \mathrm{~g}$ susu skim, $15 \mathrm{~g} \mathrm{NB}, 7.5 \mathrm{~g}$ agar dan $500 \mathrm{~mL}$ akuades. Agar, NB dan akuades disterilisasi menggunakan autoklaf pada suhu $121{ }^{\circ} \mathrm{C}$ selama 15 menit. Setelah sterlisasi selesai, susu skim ditambahkan saat media masih panas. Biakan bakteri digores pada media yang sudah ditambahi susu skim. Aktivitas proteolitik diindikasikan dengan adanya zona bening di sekitar koloni bakteri 48 jam setelah perlakuan (Pailin et al., 2001).

\section{Uji Aktivitas Melarutkan Fosfat}

Pengujian dilakukan dengan menggunakan medium Pikovskayas Agar (Himedia, India). Biakan bakteri digoreskan pada permukaan media dan diinkubasi pada suhu kamar selama 48 jam. Bakteri yang mampu melarutkan fosfat terlihat dengan adanya zona bening di sekitar goresan bakteri (Ahmad et al., 2008).

HASIL DAN PEMBAHASAN
Available online at www.jurnal.borneo.ac.id Halaman 01-10

Rhizobakteri diisolasi dari lima sampel tanah di daerah perakaran tanaman sawi di Kota Tarakan. Kelima sampel tanah memiliki kandungan bahan organik yang berbeda. Sampel pertama adalah tanah tanpa pemberian bahan organik disimbolkan dengan B1, sampel kedua tanah dengan bahan organik kotoran ayam diberi simbol B2, sampel ketiga tanah dengan bahan organik kotoran ayam dan limbah kepala udang dengan simbol B3, sampel keempat tanah dengan bahan organik kotoran ayam dan air kelapa simbolnya B4, dan sampel kelima tanah dengan bahan organik air kelapa dan limbah kepala udang dengan simbol B5. Jumlah koloni rhizobakteri yang terbanyak diperoleh dari sampel tanah B1 (tanpa pemberian bahan organik) sebanyak 184 koloni, sampel B4 menghasilkan koloni rhizobakteri yang paling sedikit yaitu 21 koloni. Jumlah total koloni yang diperoleh dari lima sampel tanah adalah 382 koloni.

Isolat rhizobakteri yang diperoleh selanjutnya diuji patogenesitasnya untuk mengetahui apakah bakteri bersifat patogen atau tidak. Pada uji patogenesitas diambil koloni yang menunjukkan perbedaan secara morfologi. Jumlah koloni yang diuji sebanyak 79 koloni isolat rhizobakteri. Uji patogenesitas dilakukan menggunakan benih mentimun Varietas Mercy. Hasil uji patogenitas menunjukkan terdapat 35 isolat rhizobakteri yang non patogen (Tabel 1.).

Tabel 1. Hasil Uji Patogenesitas Isolat Rhizobakteri

\begin{tabular}{|c|c|c|c|}
\hline No. & Sampel Tanah & Patogen & Non Patogen \\
\hline 1 & B1 & $\begin{array}{l}\mathrm{B} 11, \mathrm{~B} 12, \mathrm{~B} 13, \mathrm{~B} 14, \mathrm{~B} 15, \mathrm{~B} 16, \mathrm{~B} 18, \\
\mathrm{~B} 110, \mathrm{~B} 111, \mathrm{~B} 112, \mathrm{~B} 114, \mathrm{~B} 115, \\
\mathrm{~B} 116, \mathrm{~B} 118, \mathrm{~B} 119\end{array}$ & $\mathrm{~B} 17, \mathrm{~B} 19, \mathrm{~B} 113, \mathrm{~B} 117, \mathrm{~B} 120$ \\
\hline 2 & B2 & $\mathrm{B} 21, \mathrm{~B} 22, \mathrm{~B} 23, \mathrm{~B} 24, \mathrm{~B} 25$ & B26 \\
\hline 3 & B3 & $\begin{array}{l}\text { B33, B34, B35, B38, B312, B315, } \\
\text { B320 }\end{array}$ & $\begin{array}{l}\text { B31, B32, B37, B39, B310, } \\
\text { B311, B313, B314, B316, B319 }\end{array}$ \\
\hline 4 & B4 & $\begin{array}{l}\text { B41, B42, B47, B49, B410, B412, } \\
\text { B414, B416 }\end{array}$ & $\begin{array}{l}\text { B43, B45, B46, B48, B411, } \\
\text { B413, B415, B417 }\end{array}$ \\
\hline 5 & B5 & $\begin{array}{l}\text { B51, B53, B55, B57, B511, B516, } \\
\text { B517, B518, B520 }\end{array}$ & $\begin{array}{l}\text { B52, B54, B56, B58, B59, B510, } \\
\text { B512, B513, B514, B515, B519 }\end{array}$ \\
\hline
\end{tabular}


Keterangan: $\quad$ B1 $=$ tanah kontrol, B2=tanah $\mathrm{k}+$ pupuk kandang, $\mathrm{B} 3=$ pupuk kandang+limbah kepala udang, B4=pupuk kandang+air kelapa, B5=limbah kapala udang + air kelapa

Isolat rhizobakteri yang patogenik menyebabkan gejala nekrosis, hawar, layu, klorosis dan keriting. Rhizobakteri yang non patogen diuji lebih lanjut untuk mengetahui aktifitas fisiologisnya, karakteristik fenotipnya, dan kemampuan sebagai antifungal. Karakter morfologi meliputi warna, bentuk, elevasi, ukuran dan tepian masing-masing koloni. Secara umum koloni rhizobakteri yang diperoleh memiliki warna putih keruh. Perbedaan fenotip antara koloni disebabkan oleh faktor genetik dan interaksinya dengan faktor lingkungan (Tabel 2.).

Tabel 2. Karakteristik Fenotipe Koloni Rhizobakteri

\begin{tabular}{ccccccc}
\hline No. & $\begin{array}{c}\text { Kode } \\
\text { Isolat }\end{array}$ & Warna & Bentuk & Elevasi & Ukuran & Tepian \\
\hline 1 & B17 & Putih keruh & Circular & Flat & Punctifrom & Entire \\
2 & B19 & Putih keruh & Circular & Flat & Punctifrom & Entire \\
3 & B113 & Putih keruh & Circular & Convex & Small & Entire \\
4 & B117 & Putih keruh & Circular & Raised & Small & Entire \\
5 & B120 & Putih keruh & circular & Flat & Punctifrom & Entire \\
6 & B26 & Putih keruh & circular & Convex & Small & Entire \\
7 & B31 & Putih keruh & Circular & Raised & Punctifrom & Entire \\
8 & B32 & Putih keruh & Spindle & Flat & Moderate & Entire \\
9 & B37 & Putih keruh & Circular & Flat & Moderate & Entire \\
10 & B39 & Putih keruh & Circular & Convex & Punctifrom & Entire \\
11 & B310 & Putih keruh & Circular & Convex & Small & Entire \\
12 & B311 & Putih keruh & Irregular & Convex & Small & Undulate \\
13 & B313 & Putih keruh & Irregular & Convex & Moderate & Undulate \\
14 & B314 & Putih keruh & Irregular & Convex & Moderate & Undulate \\
15 & B316 & Putih keruh & Circular & Flat & Large & Entire \\
16 & B319 & Putih & Rhizoid & Convex & moderate & Undulate \\
17 & B43 & Putih keruh & Irregular & Convex & Moderate & Lobate \\
18 & B45 & Putih keruh & Spindle & Convex & Small & Undulate \\
19 & B46 & Putih keruh & Circular & Convex & Moderate & Undulate \\
20 & B48 & Putih keruh & Irregular & Convex & Moderate & Undulate
\end{tabular}

\begin{tabular}{ccccccc}
\hline No. & $\begin{array}{c}\text { Kode } \\
\text { Isolat }\end{array}$ & Warna & Bentuk & Elevasi & Ukuran & Tepian \\
\hline 21 & B411 & Putih keruh & Circular & Flat & Moderate & Undulate \\
22 & B413 & Putih keruh & Circular & Flat & Punctifrom & Undulate \\
23 & B415 & Putih Susu & Irregular & Convex & Large & Lobate \\
24 & B417 & Putih keruh & Circular & Convex & Small & Undulate \\
25 & B52 & Putih keruh & Circular & Flat & Moderate & Entire \\
26 & B54 & Putih keruh & Circular & Convex & Small & Entire \\
27 & B56 & Putih Kekuningan & Irregular & Flat & Small & Lobate \\
28 & B58 & Putih keruh & Circular & Convex & Small & Entire \\
29 & B510 & Putih keruh & Circular & Flat & Punctifrom & Entire \\
30 & B512 & Putih keruh & Irregular & Convex & Moderate & Undulate \\
31 & B513 & Hijau & Circular & Convex & Punciform & Entire \\
32 & B514 & Putih keruh & Circular & Flat & Punctifrom & Entire \\
33 & B515 & Putih keruh & Circular & Convex & Moderate & Entire \\
34 & B519 & Putih Kekuningan & Circular & Flat & Small & Entire \\
35 & B59 & Putih keruh & Circular & Convex & Small & Entire
\end{tabular}


Tabel 3. Hasil Uji Proteolitik

\begin{tabular}{cc}
\hline Isolat Rhizobakteri & Diameter Zona Bening (cm) \\
\hline B17 & 2,3 \\
B117 & 3,1 \\
B120 & 2 \\
B31 & 2,8 \\
B310 & 1,2 \\
B313 & 1,8 \\
B316 & 1,6 \\
B43 & 1,1 \\
B45 & 3,4 \\
B46 & 3,4 \\
B413 & 2,5 \\
B417 & 3,5 \\
B52 & 1,8 \\
B54 & 2,7 \\
B56 & 3 \\
B58 & 3,2 \\
B59 & 2 \\
B512 & 2,5 \\
B514 & 2,4 \\
B515 & 3 \\
B519 & 1,2 \\
\hline
\end{tabular}

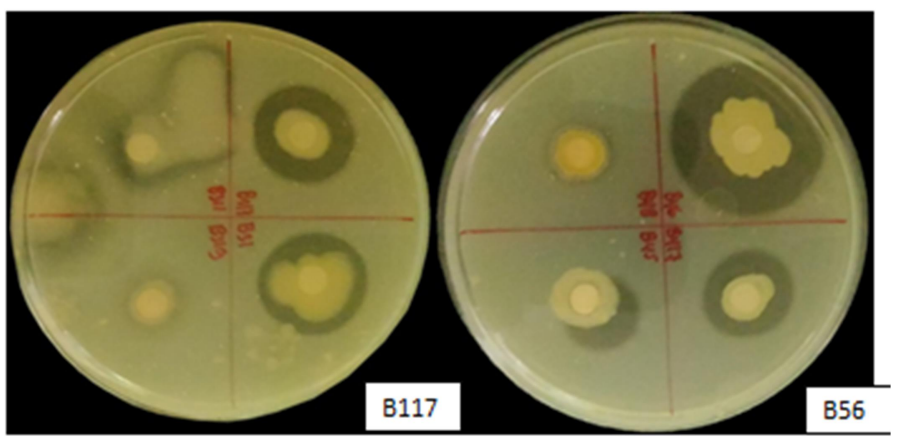

Gambar 1. Hasil Uji Pelarut Fosfat

Hasil uji aktivitas fisiologi koloni bakteri yang meliputi uji Proteolitik dan uji Pelarut fosfat terdapat pada Tabel 3 dan Gambar 1. Uji proteolitik bertujuan untuk mengetahui kemampuan rhizobakteri dalam menghasilkan enzim protease. Isolat rhizobakteri yang menunjukkan aktivitas proteolitik sebanyak 23 isolat dari 35 isolat yang diuji. Aktivitas proteolitik ditunjukkan dengan adanya zona bening. Isolat rhizobakteri yang menunjukkan aktivitas proteolitik terbaik adalah B413 dengan diameter zona bening $3.5 \mathrm{~cm}$. Hasil uji pelarut Fosfat menunjukan bahwa hanya dua isolat rhizobakteri yang memiliki kemampuan melarutkan Fosfat yaitu B117 dengan diameter zona bening $1.15 \mathrm{~cm}$ dan isolat B56 dengan diameter zona bening $1,2 \mathrm{~cm}$.

Uji antifungal rhizobakteri dilakukan terhadap Fusarium sp, dan hasil pengujian menunjukkan tidak ada isolat yang mampu menghambat Fusarium sp.

Hasil pengujian dalam penelitian ini diperoleh 35 isolate rhizobakteri non patogenik dari rizosfer tanaman sawi di Kota Tarakan. Isolat rhizobakteri yang non patogenik ini berpotensi untuk diaplikasikan baik sebagai biofertilizer (pupuk hayati) atau biopestisida untuk meningkatkan produksi pertanian di Kota Tarakan. Hasil karakteristik fenotip dari 35 
isolate rhizobakteri menunjukkan perbedaan fenotip. Perbedaan fenotip dipengaruhi erat oleh perbedaan genetik setiap bakteri. Selanjutnya fenotip juga merupakan ekspresi interaksi antara genetik dengan lingkungan (Pigliucci, 1996). Bakteri yang memiliki fenotip berbeda biasanya berasal dari genus atau spesies yang berbeda. Sedangkan bakteri dengan fenotip yang sama belum tentu memiliki genus atau spesies yang sama. Bakteri dapat memiliki fenotip yang berbeda apabila ditumbuhkan pada media yang berbeda atau media dengan cekaman tertentu (Drenkard dan Ausubel, 2002). Bakteri Ralstonia solanacearum memiliki warna putih keruh pada media nutrient agar namun apabila media tersebut ditambahkan dengan antibiotik tetrazoliumchloride (TZC). Perbedaan warna tersebut merupakan bukti bahwa fenotip merupakan interaksi antara genetik dengan lingkungan (Williamson et al., 2002).

Hasil uji proteolitik menunjukkan sebanyak 23 isolat rhizobakteri memiliki kemampuan menghasilkan enzim protease yang mampu menghidrolisa protein, dengan tingkat aktivitas proteolitik berbeda-beda. Perbedaan ini disebabkan perbedaan genetik masing-masing isolate rhizobakteri. Abraham et al., (1993) menyatakan bahwa bakteri proteolitik adalah bakteri yang memproduksi enzim protease ekstraseluler, yaitu enzim pemecah protein yang diproduksi di dalam sel kemudian dilepaskan keluar dari sel. Semua bakteri mempunyai enzim protease di dalam sel, tetapi tidak semua mempunyai enzim protease ekstraseluler. Aktivitas proteolitik ditunjukkan dengan adanya zona bening yang terbentuk di sekitar koloni bakteri. Enzim proteolitik ekstraseluler bakteri menyebabkan kasein (protein dalam susu skim pada media) terhidrolisis menjadi peptida dan asam amino yang larut, sehingga terbentuk zona bening. Aktivitas proteolitik rhizobakteri berperan dalam proses dekomposisi bahan organik tanah dan juga berperan penting dalam proses degradasi dinding sel jamur pathogen (Mahartha et al., 2013).

Hasil uji pelarut fosfat menunjukkan dua isolat rhizobakteri memiliki kemampuan melarutkan fosfat. Bakteri yang memiliki kemampuan melarutkan fosfat berpotensi sebagai pupuk hayati. Bakteri ini menskresikan enzim fosfatase yang merubah $P$ organik menjadi $P$ anorganik melalui proses hidrolisis (Purwaningsih, 2009). Selain menghasilkan enzim fosfatase, bakteri pelarut fosfat juga menghasilkan asamasam organik seperti oksalat, suksinat, fumarat dan malat yang juga berperan dalam ketersediaan $\mathrm{P}$ di dalam tanah (Suriadikarta dan Simanungkalit, 2006).

Hasil Uji Antifungal menunjukkan tidak ada isolat rhizobakteri yang mampu menghambat pertumbuhan Fusarium sp. $\mathrm{Hal}$ ini diduga isolat rhizobakteri secara genetik tidak memiliki kemampuan bakteri antagonis.

Kemampuan agen hayati dalam memproduksi senyawa antagonis dipengaruhi oleh faktor genetik dan lingkungan. Agen hayati memiliki gen yang mengatur produksi suatu enzim tetapi jika lingkungan tidak mendukung maka enzim tersebut tidak akan diproduksi. Sebaliknya, meskipun lingkungan mendukung untuk produksi suatu enzim namun jika agen hayati tidak memiliki gen yang mengatur pembentukan enzim tersebut maka enzim tidak akan terbentuk (Caldwell, 2005).

\section{KESIMPULAN}

Diperoleh 35 isolat rhizobakteri yang non patogenik, 23 isolat rhizobakteri yang memiliki aktivitas proteolitik, 2 isolat rhizobakteri yang mampu melarutkan fosfat dan tidak ada rhizobakteri yang memiliki kemampuan antifungal.

\section{UCAPAN TERIMA KASIH}

Ucapan terima kasih disampaikan kepada Universitas Borneo Tarakan khususnya 
Rektor dan LPPM Universitas Borneo Tarakan yang telah memberikan bantuan dana pada penelitian ini.

\section{DAFTAR PUSTAKA}

Abraham A. G., G. Antoni L., and Añon A. C., 1993. Proteolytic Activity of Lactobacillus bulgaricus Grown in Milk, Journal of Diary Science. La Plata, Argentina.

Ahemad M, Kibret M. 2014. Mechanisms and applications of plant growth promoting rhizobacteria: current perspective. Journal of King Saud University-Science. 26(1): 1-20.

Ahmad F, Ahmad I, Khan M. 2008. Screening of free-living rhizospheric bacteria for their multiple plant growth promoting activities. Microbiological Research. 163(2): 173-181.

Asghar H, Zahir Z, Arshad M, Khaliq A. 2002. Relationship between in vitro production of auxins by rhizobacteria and their growth-promoting activities in Brassica juncea L. Biology and Fertility of Soils. 35(4): 231-237.

Beneduzi A, Ambrosini A, and Passaglia LM. 2012. Plant growth-promoting rhizobacteria (PGPR): their potential as antagonists and biocontrol agents. Genetics and Molecular Biology. 35(4): 1044-1051.

Bhattacharyya P, Jha D. 2012. Plant growth-promoting rhizobacteria (PGPR): emergence in agriculture. World Journal of Microbiology and Biotechnology. 28(4): 1327-1350.

Bochner BR. 2008. Global phenotypic characterization of bacteria. FEMS Microbiology Reviews. 33(1): 191205.

Breedt G, Labuschagne N, Coutinho T. 2017. Seed treatment with selected plant growth-promoting rhizobacteria increases maize yield in the field. Annals of Applied Biology. 171(2): 229-236.
Buck JD. 1982. Nonstaining $(\mathrm{KOH})$ method for determination of gram reactions of marine bacteria. Applied and Environmental Microbiology. 44(4): 992-993.

Caldwell BA. 2005. Enzyme activities as a component of soil biodiversity a review. Pedobiologis. 49(6): 637644.

Castillo JD, Vivanco JM, Manter DK. 2017. Bacterial microbiome and nematode occurrence in different potato agricultural soils. Microbial Ecology. 2017(1): 1-13.

Dastager SG, Deepa C, and Pandey A. 2011. Potential plant growthpromoting activity of Serratia nematodiphila NII-0928 on black pepper (Piper nigrum L.). World Journal of Microbiology and Biotechnology. 27(2): 259-265.

Drancourt M, Bollet C, Carlioz A, Martelin R, Gayral J-P et al. 2000. 16S ribosomal DNA sequence analysis of a large collection of environmental and clinical unidentifiable bacterial isolates. Journal of Clinical Microbiology. 38(10): 3623-3630.

Drenkard and Ausubel. 2002. Pseudomonas biofilm formation and antibiotic resistence are linked to phenotypic variation. Nature. 416(6882): 740-743.

Furlan F, Saatkamp K, Volpiano CG, de Assis Franco F, dos Santos MF et al. 2017. Plant growth-promoting bacteria effect in withstanding drought in wheat cultivars. Scientia Agraria. 18(2): 104-113.

Garća JAL, Domenech J, Santamaría C, Camacho Ma, Daza A et al. 2004. Growth of forest plants (pine and holm-oak) inoculated with rhizobacteria: relationship with microbial community structure and biological activity of its rhizosphere. Environmental and Experimental Botany. 52(3): 239-251. 
Gupta G, Parihar SS, Ahirwar NK, Snehi SK, Singh V. 2015. Plant growth promoting rhizobacteria (PGPR): current and future prospects for development of sustainable agriculture. Journal of Microbiology and Biochemical Technology. 7(2): 096-102.

Joseph B, Ranjan Patra R, Lawrence R. 2012. Characterization of plant growth promoting rhizobacteria associated with chickpea (Cicer arietinum L.). International Journal of Plant Production. 1(2): 141-152.

Karim H, Kuswinanti T, Rosmana A, Rasyid B. 2015. Effectiveness of fungal and bacterial isolates from rhizosphere of passion fruits againts Fusarium oxysporum f. sp passiflorae in Vitro. International Journal of Agriculture System. 1(2): 120-126.

Lecomte C, Alabouvette C, Edel-Hermann V, Robert F, Steinberg C. 2016. Biological control of ornamental plant diseases caused by Fusarium oxysporum: a review. Biological Control. 101(1): 17-30.

Liu K, Newman M, McInroy JA, Hu C-H, Kloepper JW. 2017. Selection and assessment of plant growthpromoting rhizobacteria (PGPR) for biological control of multiple plant diseases. Phytopathology. 107(8): 928-936.

Lopez BR, Bashan Y, Bacilio M. 2011. Endophytic bacteria of Mammillaria fraileana, an endemic rock-colonizing cactus of the southern Sonoran Desert. Archives of Microbiology. 193(7): 527-541.

Mahartha, K.A., Khalimi, K. \& Wirya, G.N.A.S. 2013. Uji Efektivitas Rhizobakteri sebagai Agen Antagonis terhadap

Fusarium oxysporum f.sp. capsici Penyebab Penyakit Layu Fusarium pada Tanaman Cabai Rawit (Capsicum frutescens L.). E-Jurnal
Agroekoteknologi Tropika. 2 (3): 145-154.

Meena KS, Ramyabharathi S, Raguchander T, Jonathan E. 2015. Meloidogyne incognita and Fusarium oxysporum interaction in Gerbera. African Journal of Microbiology Research. 9(18): 1281-1285.

Meena KS, Ramyabharathi S, Raguchander $T$, Jonathan E. 2016. Interaction of Meloidogyne incognita and Fusarium oxysporum in carnation and physiological changes induced in plants due to the interaction. SAARC Journal of Agriculture. 14(1): 59-69.

Nelson LM. 2004. Plant growth promoting rhizobacteria (PGPR): Prospects for new inoculants. Crop Management. 3(1): 121-128.

Nurulhuda M, Latiffah Z, Baharuddin S, Maziah Z. 2009. Diversity of fusarium species from vegetable fruits. Journal Malaysian Applied Biology. 38(1): 4347.

Pailin T, Kang D, Schmidt $K$, Fung D. 2001. Detection of extracellular bound proteinase in EPS-producing lactic acid bacteria cultures on skim milk agar. Letters in Applied Microbiology. 33(1): 45-49.

Paramanandham P, Rajkumari J, Pattnaik S, Busi S. 2017. Biocontrol potential against Fusarium oxysporum f. sp. lycopersici and Alternaria solani and tomato plant growth due to plant growth-promoting rhizobacteria. International Journal of Vegetable Science. 23(4): 1-10.

Penrose DM, Glick BR. 2003. Methods for isolating and characterizing ACC deaminase-containing plant growthpromoting rhizobacteria. Physiologia Plantarum. 118(1): 10-15.

Pigliucci. 1996. How Organisms Respond to Environmental Changes: From Phenotypes to Molecules (and Vice Versa). Trends in Ecology and Evolution. 11:168-173.30. 
JURNAL BORNEO SAINTEK

Volume 2, Nomor 2, Oktober 2019

e-ISSN 2599-3313

p-ISSN 2615-434X

Ploetz RC. 2006. Fusarium wilt of banana is caused by several pathogens referred to as Fusarium oxysporum $\mathrm{f}$. sp. cubense. Phytopathology. 96(6): 653-656.

Pradana AP. 2016. Konsorsium bakteri endofit sebagai agens biokontrol nematoda puru akar Meloidogyne incognita pada tomat. Tesis. Institut Pertanian Bogor. Bogor.

Purwaningsih S. 2009. Populasi Bakteri Rhizobium di Tanah pada Beberapa Tanaman dari Pulau Buton. Jurnal Tanah Tropika. 14(1): 65-70.

Rubin RL, van Groenigen KJ, Hungate BA. 2017. Plant growth promoting rhizobacteria are more effective under drought: a meta-analysis. Plant and Soil. 416(1): 1-15.

Suriadikarta dan Simanungkalit, 2006. Pupuk Organik dan Pupuk Hayati. Balai Besar Penelitian dan Pengembangan Sumberdaya Lahan Pertanian. Bogor. http//balittanah.litbang.deptan.go.id.

Sadras V, Richards R. 2014. Improvement of crop yield in dry environments: benchmarks, levels of organisation
Available online at www.jurnal.borneo.ac.id Halaman 01-10

and the role of nitrogen. Journal of Experimental Botany. 65(8): 19811995.

Thakuria, D., N.C. Talukdar, C. Goswami, S. Hazarika, R.C.Boro, M.R. Khan. 2004. Characterization and screening of bacteria from rhizosphere of rice grown in acidic soils of Assam. Current Sci. 86:978985.

Williamson, R.M., M. Primig, Brian K.W., Elizabeth A.W., Michel B., Cyril S de Menthiere, Ronald W.D., and Rochele E.E. 2002. The Ume6 regulon coordinates metabolic and meiotic gene expression in yeast. PNAS. October 15, 2002. 99(21): 1343113436.

https://doi.org/10.1073/pnas.20249 5299.

Xiang Lu, Xuan Zhou, Yu Cao, Meixue Zhou, David McNeil, Shan Liang, and Chengwei Yang. 2017. RNA-seq Analysis of Cold and Drought Responsive Transcriptomes of Zea mays ssp. mexicana L. Frontiers in Plant Science. 8:136. doi: 10.3389/fpls.2017.00136. 
